\title{
Determinants of Job Stress and Its Relationship on Employee Job Performance
}

\author{
Revenio Jalagat \\ Managerial and Financial Sciences Department, Al-Zahra College for Women, Muscat City, Sultanate of Oman
}

Email address:

revjalagatjr@gmail.com

\section{To cite this article:}

Revenio Jalagat. Determinants of Job Stress and Its Relationship on Employee Job Performance. American Journal of Management Science and Engineering. Vol. 2, No. 1, 2017, pp. 1-10. doi: 10.11648/j.ajmse.20170201.11

Received: December 31, 2016; Accepted: January 10, 2017; Published: February 3, 2017

\begin{abstract}
Stress happens in workplaces and it arises at different levels. Job stress is becoming an alarming situation in the workplace. This study is aimed at determining job stress variables that affect employee performance. It also determine the relationship between job stress and employee performance. To achieve this objective, the study was conducted to Petroleum Development Oman (PDO) in Al-Bahja Center to 65 respondents. The study employed the descriptive research design using the survey questionnaires as its instruments and utilized the purposive sampling to obtain the sample. Originally. Questionnaires were distributed to 80 respondents but only 65 questionnaires were retrieved and analyzed. Highlights of the findings indicated that, there is significant relationship between job stress and employee performance with $\mathrm{r}=0.955$. When analyzed the independent variables individually using regression analysis, results revealed that both independent variables: underutilization of skills and work overload significantly correlates to employee performance with p-values 0.000 $(\mathrm{p}=0.000<0.05)$ and $0.033(\mathrm{p}=0.033<0.05$ respective which were lower than 0.05 level of confidence while there was no significant relationship between role ambiguity $(\mathrm{p}=0.324>0.05)$ and employee performance. Based on these findings, it can be recommended that the company should consider underutilization of skills and work overload as predictors of employee performance. The company should put consideration on developing the skills of the employees and tapping their potentials. The Human Resource Department may conduct as appropriate skills inventory to identify talents and potentials of employees with proper motivation as well as revisit their policies on promotion. However, it also recommended that further studies can be conducted to consider larger sample, scope and more variables as appropriate to arrive at more reflective results.
\end{abstract}

Keywords: Job Stress, Employee Job Performance, Role Ambiguity, Underutilization of Skills, Overload

\section{Introduction}

One of the common challenges that employees are experiencing in the workplace anywhere in the world is the so called stress. Stress is said to influence employees' performance and efficiency. Thus, stress has become a burning issue that firms have to consider in order for employees to perform their tasks with efficiency and effectiveness. In fact, stress can attribute to one life's imbalance that may also lead to depression as well as conflicts such as workplace conflict, role conflict, role ambiguity and workload. Consequently, the impact of stress has been investigated broadly on students $[1,8,14,33]$, academic staff $[9,12,20,22,42, \& 43]$, bankers $[4,45, \&$ $46]$, the public sector $[2,11,47, \& 48]$, the private sector $[40$, $19]$, and the health sector [30].
Most of organizations in the modern days find several means and ways to ensure that their businesses achieves the organizational goals and sustain profitability. However, they often mislead with the notion that when the business and the people are in stressful conditions it is likely that company's performance is affected. It is a growing concern in businesses today that stress has becoming a serious threat not only to individual employees but also to the organization as a whole. For some companies, coping up with stress has become an integral part of their organizational plan and institute many programs on how to overcome stressful situations and conditions although for others, they have not yet realized the impact of stress to the well-being of the individual and the organization. The truth is, stress can affect the employee's 
and organization's performance, something that can be alarming. So, this study sought to clarify the effect of stress on staff and evaluates the performance of the staff particularly those under pressures brought about by their job, identify the causes and factors of job stress and look for ways to solve and prevent the stress to occur, minimize or reduce the impact to acceptable level.

\subsection{Statement of the Problem}

Job Stress is considered as a serious problem for employees since it affect and influence employees' mental, physical and well-being. Many companies perceived stress as strong predictor to employee performance. It is also common notion that when employees are under stressful situation, they likely perform less than expectations. When considering the chosen organization, Petroleum Development of Oman (PDO) has been operating for quiet long time since its inception. It is observed that the volume of work in the company is voluminous that employee sometimes complain on the magnitude of work to be attained daily that resulted to work overloads. This motivated the researcher to conduct a study to determine the determinants of stress in the workplace and its relationship on employee performance.

\subsection{Research Objectives}

This study attempted to determine the relationship between job stress and employee performance. The specific objectives of the present study is/are as follows:

1. To determine the level of Job stress according to the following factors: role ambiguity, underutilization of Skills, and work overload and its impact on employee work performance.

2. To determine the relationship between the following job stress factors on employee performance.
a Role Ambiguity
b Underutilization of Skills
c Work Overload

\subsection{Research Questions}

Specifically, this study sought to address the following research questions:

1. Is there relationship between job stress and employee performance

2. Is there significant relationship between role ambiguity and employee performance.

3. Is there significant relationship between underutilization of skills and employee performance?

4. Is there significant relationship between work overload and employee performance?

\subsection{Research Hypotheses}

Based on the objectives of the study, the following hypotheses can be drawn.

$\mathrm{H}_{\mathrm{o}} 1$. There is no significant relationship between job stress and employee performance

$\mathrm{H}_{0} 2$. There is no significant relationship between role ambiguity and employee performance.

$\mathrm{H}_{0} 3$. There is no significant relationship between underutilization of skills on employee performance.

$\mathrm{H}_{0} 4$. There is no significant relationship between work overload and employee performance.

\subsection{Significance of the Study}

Stress is undeniably considered as the most common problem existing in organization but it is also a big factor for low quality employee performance and less productivity. For companies to succeed and overcome this barrier, it is important that employees work in a stress free environment so that problems related to employee efficiency, absenteeism and turnover will be decreased if not eliminated. Therefore, it is important to study the relationship between job stress and employee performance. The importance of job stress can be expressed through various factors such as workload, role ambiguity, and underutilization of skills. This is very important especially with the chosen organization, PDO because the result of this study can be used as benchmarks by companies considering that PDO is the largest producer of oil in the country. The recommendations can be relevant for further studies.

\section{Literature Review}

There can be many factors that cause job stress. These may include but not limited to the following: work overload; role ambiguity; role conflict; responsibility for people; participation; lack of feedback; keeping up with technology; having an innovative role; career growth; organizational structure and environment; and recent episodic events [21, 24, 36, and 38]. Depending upon the situation of the companies, these factors may apply as situations and conditions vary from business to business.

\subsection{Concepts and Definition of Job Stress}

Bashir's ( definition of stress is associated with the person's state of thinking and mindset that deviates from the natural and regular state of mind which may cause abnormal functioning leading to the state of mentally disturbed in psychologically and emotionally. It is considered functioning beyond what is normal and acceptable. Influenced by this concept modern researches acknowledged that stress is part and parcel of the job in the workplace and it cannot be avoided however it can be managed and controlled or minimized to acceptable level. According to Mimura \& Griffith [29] stress is something or a condition where the person is faced with constant pressure that normally arise in the workplace known as work pressures like short notices and deadlines, undesirable health conditions, family pressures and others. When people are faced with situations where requirements in the work are so huge that they have difficulty to manage, it affects their mental being and disposition that will also attribute to physical and behavioral problems. 
Treven [44] find the same consensus indicating that stress is part of life that applies not only to employees but to all individuals regardless of ranks and positions. He also found out that it is about 100 million working days as a result of stress and relate to approximately $50 \%$ to $75 \%$ disease stress. The loss of focus and enthusiasm in the work is the major cause of stress that also increase the level of risk and the second cause is the tension. Both of these impacts negatively to employee's work performance and the achievement of organizational goals.

\subsection{Employee Job Performance}

Employee Job performance is viewed as associate degree activity during which a person is ready to accomplish the task allotted to him/her with success, subject to the traditional constraints of cheap utilization of the obtainable resources [13]. At an abstract level, four sorts of relationships were projected to exist between the measures of job stress and job performance. One of the negative linear relationships is that, once productivity decreases with stress. Productivity may also increase as a consequence of stress, thereby implying a positive linear relationship between the two. Thirdly, there can be a U-shaped or a curved relationship whereby, delicate stress may increase the productivity ab initio up to a peak and so it declines because the person descends into a state of distress [10]. Meyer \& Peng [27] as cited in the study of Jalagat [17], employee job performance refers to the output that a person has contributed to the organization concerning his behavior to engage in, and which the organization may perceive it as productive or counterproductive.

\subsection{Job Stressors}

Stamper \& Johlke [41] there are many reasons for the occurrence or incidence of stress and it may consists of the following: work conflict, family matters, work overload, role ambiguity and conflict, etc. They further added that, if the management is not concern or will not recognize the employee's efforts, the stress level on the part of employees will remain. Hence, further scenario would be many of those employees will leave the organization. Furthermore, Rose [34] introduced the eleven forces that are used as an antecedents of stress by researches such as work overload, role ambiguity, role conflict, responsibility for people, participation, lack of feedback, keeping up with quick technological change, being in an innovative role, career growth, organizational structure and environment, and recent episodic events. Anderson [6] cited the common reasons for stress that include work overloads, role ambiguity, underutilization of skills and many others.

Barrick and Taukari [32] exclaimed that, there are four stressors that negatively affects the performance in the workplace according to that includes work environment, including the holiday weekend, and not enough pay, hours of taste, and work and safety in the work environment. Secondly, and relationships in work, including the quality of relationships with subordinates, colleagues and supervisors.
Thirdly, the role conflict and lack of clarity of role, functions, and expectations, and duties. Fourth, the organizational structure and climate, which includes communication policy to live by, significant changes in the workplace, and culture of the organization, lack of input in the decision-making. Another reason is career development, including in the framework of the process of skills or the failure to reach full. Another factor is the nature of the task that may amount to a great deal of fatigue and physical movement.

However; in this study, the variables used include: role ambiguity; role overload; underutilization of skills as deemed applicable to the situation in PDO.

\subsection{Role Ambiguity, Underutilization of Skills and Work Overload}

Role ambiguity as defined refers to the lack of enough data and information that deals about powers and authority as well as duties to be performed by employees [21, \& 15]. Role Ambiguity operates when the employee is in the stage of confusion on how he will perform the tasks or when an employee is asked to do the task without clear instructions and no clear responsibilities assigned to him resulting to role confusion. Underutilization of skills refers to skills that an employee possess but not utilized at optimum level and its occurs when one's ability to perform beyond expectation is not enhanced. It also refers to the underemployment of workers who possess high skills working in relatively lowskilled and low wage jobs [6]. Work overload is defined by Margolis et al. [24] and Schultz and Schultz [38] when the person is incapable to do the job due to excessive responsibilities beyond his capability to perform or the nonending tasks more than what the employee can bear.

\subsection{Relationship of Job Stress on Employee Performance}

Several studies have also found out that job stress affects negatively to the overall performance of the employees considering the various factors involved and specifically to the employee's job satisfaction. Since, many companies nowadays are emphasizing more on demanding works/tasks that also requires superior outcomes, it builds numerous stressors that further creates challenging situations for individuals thus, more incidence of stressful situations [29, 31, 34, \& 41].

Recent studies confirmed that, job stress significantly decreased the performance of employees especially in the banking sector $[3,16]$. Specifically, they added that there is negative correlation between job stress and employee performance. Similar study was conducted by Ali, et. al. [5] and found out that, factors such as workload, role conflict and inadequate monetary rewards are the prime reasons for job stress that causes decrease in performance of employees. Furthermore, Jeyarai [20], investigated the impact of occupational stress among teachers and findings revealed that, stress causes teachers to commit absences, tendencies to quit teaching and less likely to pursue teaching career, hence; negatively correlated. The same findings were experience in 
the study of Dundamde, Adegoke and Agboola [12] related to techno-stress among university workers and main findings showed that, stress negatively impacts employee performance. This is also affirmed in the study of Suandi, Ismael and Othman [42] who have arrived at similar findings indicating the negative relationships between job stress and job performance.

Sheena [39] found that the impact of underutilization of skills, low wages, and dissatisfied aspiration on employee's profession sequencing the entire sources of stress, Lankau, et.al. [23]; considered that correlations at job with leaders and partners, together with discrimination in the place of work might affect in a collection of stress. At a managerial rank, the makeup and atmosphere, as well as the scale of contribution in judgment building and contribution in organizations tactful possibly will product in a traumatic atmosphere. Hence, as a consequence employee's performance could be influenced via all these changeable at the place of work. Along with the mainly influenced variables that influence the employee's performance are role ambiguity, work overload, and underutilization skills.

Meneze [26] added that, work stress even though maybe interpreted by some companies as low alarming situations can pose higher impact on individual's health that also directly affects his performance. Accordingly, the incidence of job stress is on upward trend that has become major challenges/problems of the employers as it reduces performance level in the job, growing cases of employee's absences, contributes to the employee's growing involvement to alcoholism, drug abuse, hypertension and host of cardiovascular problems. Furthermore, personality factors revealed its influence or contribution to stress, anxiety and other health-related problems that creates challenges especially in the increasing cases of stress as well, no satisfaction in the job by employees and individuals [28].

Mead [25] concluded in his study the impact of stress in job performance. He pointed out that there is negative impact of job stress on employee performance if the stress is not managed efficiently. Accordingly, too much stress negatively impacts the work performance of both the employees and the organization. Similarly, Jamal [18] proved in his study that there is a link between job stress and employee performance between managers and staff. He uses the variables such as job stress, performance and organization commitment and its relationships and found out that there is negative impact between job stress and job performance and also emphasized the negative impact of pressures in the workplace.

\subsection{Conceptual Framework}

This research firstly investigated the level of stress and its impact on employee work performance. Secondly, it also assess and evaluate the relationship between the job stress factors (role ambiguity, underutilization of skills, and work overload) on employee performance.

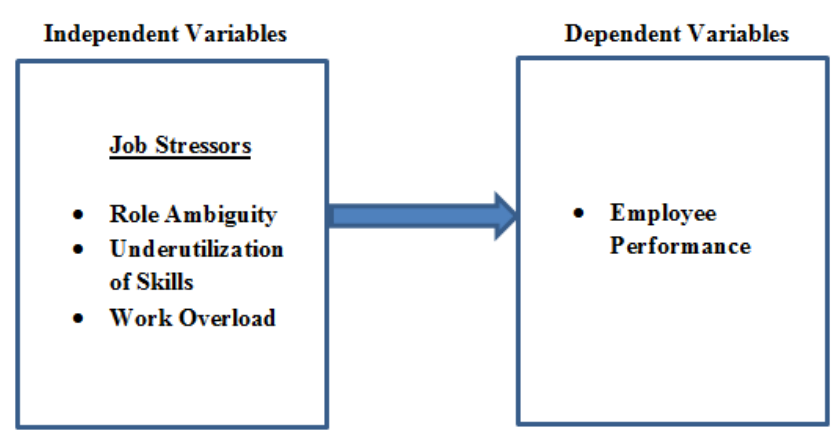

Figure 1. Conceptual Framework.

\section{Research Methodology}

\subsection{Research Design}

The study used descriptive research design to determine the Relationship between Job Stress and Employees Performance in Petroleum Development Oman. Descriptive design is a purposive process of gathering, analyzing and tabulating data about prevailing conditions, practices, beliefs, processes, trends and cause and effect relationship and then making adequate and accurate interpretation about such data with the aid of some simple percentile and statistical method [37]. Primarily it utilizes the quantitative method employing the survey questionnaires.

\subsection{Research Locale}

One of the leading company involved in the exploration of oil is the government oil company known as the Petroleum Development Oman (PDO) in the entire Sultanate of Oman. It has also performed the role of regulators of oil companies operating in the country that accounts to more than $70 \%$ of the Sultanate's crude oil production as well as most of the natural gas supply. As a government owned Corporation Company, its ownership composition is $60 \%$ owned by Government of Oman; 34\% owned by the Royal Dutch Shell, and the Total and Prates with $2 \%$. The company started its operation way back in 1962 as the exploration and determination of the oil deposit has been discovered to be the first discovery and its operates into consignment of the oil through its first export in 1967.

In addition, PDO operates in a concession area of about $100,000 \mathrm{~km} 2$ (one third of Oman's geographical area), has around 130 producing fields, close to 6,000 producing wells, a diverse workforce of around 8,000 employees, comprised of 64 different nationalities along with more than 45,000 contractors.

\subsection{Population and Sample}

This study mainly utilized the purposive sampling based on the professional judgment of the researcher. In tabular format, the 65 respondents were taken from the different departments from a total population of 8,000 employees. 
Table 1. Distribution of Respondents by Department.

\begin{tabular}{lll}
\hline Department & f & Percent \\
\hline Finance \& Administration & 5 & 8.00 \\
Programs & 18 & 28.00 \\
Monitoring \& Evaluation & 10 & 15.00 \\
Advocacy and Research & 15 & 23.00 \\
Training and Capacity Building & 17 & 26.00 \\
Total & 65 & 100.00 \\
\hline
\end{tabular}

\subsection{Research Instrument}

The survey research questionnaires were employed in this study. The question is divided into two parts. The first part contains questions pertaining to the demographic profile of the respondents according to the following: employee gender, education level and employee age. The second part shows questions to assess the level of stress and its impact on employee performance from the three identified independent variables: role ambiguity, underutilization of skills, and work overload using self-made questionnaires. The Likert Scale model were used that follows the format: 5=Strongly Agree (SA); 4=Agree (A); 3=Neither Agree/Disagree (NA/D); 2=Disagree (D); $1=$ Strongly Disagree.

\subsection{Research Procedures}

To obtain the data, the researcher visited the company and sought the permission of the management with the letter of consent. Upon approval, the questionnaires were distributed after explaining the objective of the research to 80 employees However, only 65 questionnaires were retrieved and validated after three weeks.

\subsection{Data Analysis}

The data will be analyzed using the SPSS statistical tool. The first part will be analyzed using the frequencies and percentages corresponding the employee gender, education level and age. The second part is analyzed utilizing weighted mean, standard deviation, correlation and regression analysis. Specifically, in treating the questions on the level of stress on employee performance, weighted mean and standard deviation were employed to independent and dependent variables. However, correlation analysis was used to determine the relationship between job stress and employee performance at 0.05 level of significance. Downhill linear relationship of correlation coefficient suggests that, 0 means no relationship;.30 is considered weak correlation; 0.50 is moderate; and 0.70 is strong correlation [35]. On the other hand, regression analysis were used to determine the significant relationship between individual independent variables: role ambiguity, underutilization of skills, work overload and employee performance.

\section{Results and Discussions}

This section presents the analysis of the information gathered in this study by using the appropriate statistical tools.

\subsection{Demographic Profile of the Respondents}

Table 2. Distribution of Respondents by Gender.

\begin{tabular}{lll}
\hline Gender & f & Percent \\
\hline Male & 45 & 69.20 \\
Female & 20 & 30.80 \\
Total & 65 & 100.00 \\
\hline
\end{tabular}

Table 2 shows that, male respondents represent the majority with $69.20 \%$ while the female represent only $30.8 \%$ of the total sample. This means that more participation of male in this study. Predominantly, more male in the workforce which is reflective of the country's culture that men should work.

Table 3. Distribution of Respondents by Education level.

\begin{tabular}{lll}
\hline Educational Level & f & Percent \\
\hline PhD & 3 & 4.62 \\
Master & 10 & 15.38 \\
Bachelor & 31 & 47.69 \\
Secondary School & 20 & 30.77 \\
Below Secondary & 1 & 1.54 \\
Total & 65 & 100.00 \\
\hline
\end{tabular}

The table shows that $47.69 \%$ or the highest number of employees are holding bachelor's degree while the second highest or $30.77 \%$ are Secondary School Certificate holders. There are 10 master's degree holders or $15.38 \%$ and $\mathrm{PhD}$ Holders with $4.62 \%$. Only 1 employee or $1.54 \%$ is categorized under below secondary school.

Table 4. Distribution of Respondents by Age.

\begin{tabular}{lll}
\hline Age & f & Percent \\
\hline $20-29$ & 18 & 27.70 \\
$30-39$ & 25 & 38.50 \\
$40-49$ & 20 & 30.80 \\
More than 50 years & 2 & 3.10 \\
Total & 65 & 100.00 \\
\hline
\end{tabular}

The table above shows that the highest participants are in the age between $30-99$ with rate of $38.5 \%$, and the participant between age $40-49$ are represented $30.8 \%$ of the total participant, ages $20-29$ has $27.7 \%$ while the lowest participants are those More than 50 years old with only $3.1 \%$. The results further reflects that, more employees are in their middle ages. 


\subsection{Role Ambiguity, Underutilization of Skills, Work Overload and Employee Performance}

Table 5. Level of Stress on Employee Performance: Role Ambiguity.

\begin{tabular}{|c|c|c|}
\hline Items & Mean & Std. Deviation \\
\hline 1. The goals of the department are not clearly stated. & 3.48 & 0.83 \\
\hline 2. My job requires too much efforts and support which are not available to me. & 3.57 & 0.86 \\
\hline 3. I am under stress most of the time due to unclear procedures that could affect my performance. & 3.89 & 0.77 \\
\hline 4. This company really deprives the best in me because of role confusion. & 4.12 & 0.89 \\
\hline $\begin{array}{l}\text { 5. I feel that everyone prefers to impose themselves with regards to their perceived individual roles than following what } \\
\text { should be their organizational roles. }\end{array}$ & 3.63 & 0.94 \\
\hline 6. I feel that it is difficult to establish a clear path that I need to do with my job properly. & 3.62 & 1.03 \\
\hline 8. The structure of my work units is not clear which reduce my contribution in enhancing the organizational performance. & 3.18 & 0.78 \\
\hline 9. I am often confused in setting the priorities of tasks to be achieved. & 3.69 & 0.88 \\
\hline Role Ambiguity & 3.66 & \\
\hline
\end{tabular}

1=Strongly Disagree; 2=Disagree; 3=Neither Agree nor Disagree; 4=Agree; Strongly Agree

Table 5 shows the respondents on the level of stress on employee performance in terms of role ambiguity. On the average, the weighted mean for role ambiguity is 3.66 which can be interpreted that there is likelihood of agreement that role ambiguity impacts employee performance. Individually, the highest mean of 4.12 shows the agreement on the statement "This Company really deprives the best in me because of role confusion. The weighted mean of 3.89 is ranked in second place which reflects that "I am under stress most of the time due to unclear procedures that coud affect my performance". While the lowest mean of 3.18 reflects the response that "The structure of my work units is not clear which reduce my contribution in enhancing the organizational performance" which is reflective of the respondents neutral responses. Further, these findings imply that, in the workplace setting the cases of role ambiguity happens when employees are confused on their roles and responsibilities and don't have enough input in deciding work-unit goals.

Table 6. Level of Stress on Employee Performance: Underutilization of Skills.

\begin{tabular}{lll}
\hline Items & Mean & Std. Deviation \\
\hline 10. My job does not offer me the opportunity to grow as a person. & 0.90 \\
11. I felt that I can perform more than expected but I am not given chances. & 3.46 \\
12. I feel that my knowledge, skills and abilities will stagnate as long as I am here. & 3.34 & 0.87 \\
Underutilization of Skills & 0.76 & 3.46 \\
\hline
\end{tabular}

1=Strongly Disagree; 2=Disagree; 3=Neither Agree nor Disagree; 4=Agree; Strongly Agree

Table 6 shows the level stress on employee performance in terms of underutilization of skills. The results shows that in general, the average weighted mean of 3.42 explains the neutrality of the employee's responses which "Neither Agree or Disagree". The results from the three questions revealed the outcome which are below the weighted mean of 3.5. This can be interpreted that the level of stress may not be evident with underutilization of skills.

Table 7. Level of Stress on Employee Performance: Work Overload.

\begin{tabular}{|c|c|c|}
\hline Items & Mean & Std. Deviation \\
\hline 13. I am responsible to accomplish too many tasks which affect my concentration and performance. & 3.52 & 0.79 \\
\hline 14. I would accept almost any type of job assignment even if I feel tired in order to maintain my performance at higher level. & 3.78 & 0.95 \\
\hline 15. Lack of cooperation of my colleague in finishing many tasks affects my performance. & 3.49 & 0.78 \\
\hline 16. I am involved in various responsibilities and hold too many roles. & 3.23 & 0.82 \\
\hline Work Overload & 3.51 & \\
\hline
\end{tabular}

1=Strongly Disagree; 2=Disagree; 3=Neither Agree nor Disagree; 4=Agree; Strongly Agree

Table 7 shows the level of stress on employee performance with work overload. Results revealed the average weighted mean of 3.51 which is reflective of the responses that they neither agree nor disagree that work overload affects employee performance. This might also mean that, because of the volume of work processed on the daily basis, they are likely used with more loads at work. However, it can be noticed that, on the response "I would accept almost any type of job assignment even if I feel tired in order to maintain my performance at a higher level" is existing in the workplace something that might affect negatively employee performance. This further indicates that because of the volume of work in the company, tendencies are that the employees will be assigned to as many jobs as possible that will affect their performance and will end the days with tiresome and stressful jobs. 
Table 8. Employees Performance.

\begin{tabular}{lll}
\hline Item & Mean & Std. Deviation \\
\hline 17. I make some errors unintentionally when I am under pressure. & 3.60 & 0.79 \\
18. My performance reduced because of lack of equitable standards in distributing of the tasks and responsibilities & 3.26 & 0.76 \\
19. My performance has been affected by unclear organization's planning and control efforts. & 3.43 & 1.01 \\
20. I can always talk with someone at work if I have a work- related problem. & 3.57 & 0.73 \\
Overall performance & 3.47 & \\
\hline
\end{tabular}

=Strongly Disagree; $2=$ Disagree; $3=$ Neither Agree nor Disagree; $4=$ Agree; Strongly Agree

The overall performance shows the likelihood that the level of stress in the workplace may not reflect its impact on employee performance as reflected with the responses "Neither Agree nor Disagree". This can be interpreted that, stress is something normal that employees may not consider it a big factor or consideration to affect employee performance. Specifically, the weighted mean of 3.60 has the highest ratings which states that "I make some errors unintentionally when facing work pressures followed by 3.57 that says "I can always talk with someone at work if I had work-related problem.

\subsection{Correlations and Regression}

One way to assess the relationship between variables is to correlate them with each other. In most researches either the Pearson product - moment correlation or the Spearman correlation coefficient is used. As applied in this study, correlation was used to determine the relation between job stress and employee performance. Build on downhill linear relationship, $\mathrm{r}=0$, means no relationship, 0.30 is weak correlation; 0.50 is moderate, and 0.70 has strong relationship between variables.

Table 9. Correlation between the Job Stress and Employee Performance.

\begin{tabular}{llll}
\hline & & Employee Performance & Leadership Style \\
\hline \multirow{3}{*}{ Employee Performance } & Pearson Correlation & 1 & .955 \\
& Sig. (2-tailed) & & .000 \\
Job Stress & N & 65 & 65 \\
& Pearson Correlation & .955 & 1 \\
& Sig. (2-tailed) & .000 & \\
& $\mathrm{~N}$ & 65 & 65 \\
\hline
\end{tabular}

* Correlation is significant at the 0.05 level (2-tailed)

The result of correlation shows strong correlation between job stress and employee performance at $\mathrm{r}=.0955$ tested at 0.05 level of significance. This would also mean the significant $p$-value of $0.000 \quad(p<0.05)$ indicating the significant relationship between the two variables. Therefore the null hypothesis is rejected. This finding is consistent with the various studies affirming that, job stress significantly affects employee performance [18, 25, 31, 34, \& 41]. This implies that, in the chosen organization it is evident that job stress significantly affects the employee performance.

Table 10. Relationship between job stressors: Role Ambiguity, Underutilization of Skills, Work Overload and Employee Performance.

\begin{tabular}{|c|c|c|c|c|}
\hline \multicolumn{5}{|c|}{ Regression analysis } \\
\hline \multicolumn{5}{|c|}{ Model Summary } \\
\hline Model & $\mathrm{R}$ & R Square & Adjusted R Square & Std. Error of the Estimate \\
\hline 1 & $.979^{\mathrm{a}}$ & .959 & .957 & 4.187 \\
\hline
\end{tabular}

\begin{tabular}{|c|c|c|c|c|c|c|}
\hline \multicolumn{7}{|c|}{ ANOVA $^{b}$} \\
\hline & & Sum of Squares & df & Mean Square & & Sig. \\
\hline \multirow{3}{*}{1} & Regression & 50.745 & 3 & 16.915 & 482.3704127 & $.000^{\mathrm{a}}$ \\
\hline & Residual & 2.139 & 61 & 0.035 & & \\
\hline & Total & 52.885 & 64 & & & \\
\hline
\end{tabular}

\begin{tabular}{|c|c|c|c|c|c|c|}
\hline \multicolumn{7}{|c|}{ Coefficients $^{\mathrm{a}}$} \\
\hline \multirow{2}{*}{\multicolumn{2}{|c|}{ Model }} & \multicolumn{2}{|c|}{ Unstandardized Coefficients } & \multirow{2}{*}{$T$} & \multirow{2}{*}{ Sig. } & \multirow{2}{*}{ Statistical Decisions } \\
\hline & & B & Std. Error & & & \\
\hline \multirow{4}{*}{1} & (Constant) & .197 & .089 & 2.193 & .032 & \\
\hline & Role Ambiguity & .059 & .115 & 0.994 & .324 & $\mathrm{H}_{0} 2$, accepted \\
\hline & Underutilization of Skills & .603 & .069 & 8.631 & .000 & $\mathrm{H}_{0} 3$, rejected \\
\hline & Work Overload & .240 & .110 & 2.174 & .033 & $\mathrm{H}_{0} 4$, rejected \\
\hline
\end{tabular}

a. Predictors: (Constant), Role Ambiguity, Underutilization of Skills, Work Overload

b. Dependent Variable: Employee Performance 
Table shows the result of regression for the three independent variables and the dependent variable. Further it reveals that the $\mathrm{R}^{2}=.959$ reflects good fit of data. It explained that about $95.9 \%$ of the variation of the dependent variable (employee performance) can be explained by the three independent variables (Role Ambiguity, Underutilization of Skills, and Work Overload). It also evident that the use of Regression ANOVA is an appropriate statistical with $\mathrm{F}$ value of 482.37 and significance of 0.000 .

The coefficient table shows that independent variables underutilization of skills and work overload significantly impacts employee performance with p-values 0.000 and 0.033 respectively while there is no significant relationship between role ambiguity and employee performance as evidenced by the $\mathrm{p}=0.324$. This finding contradicts to the previous studies conducted indicating that role ambiguity correlates to employee performance [23, 28]. Therefore null hypotheses are rejected for underutilization of skills and work overload while the hypothesis for role ambiguity is accepted that there is no significant relationship between role ambiguity and employee performance at 0.05 level of significance. However; role ambiguity has been confirmed in other studies to have significant relationship on employee performance. Those findings were not the same case with the PDO considering that the company has clear-cut policies with regards to employee job responsibilities, organization's procedures and guidelines on how people perform in their respective jobs. So, employees are well aware of their roles towards their jobs.

\section{Conclusion}

This study is sought to determine the relationship between job stress and employee performance. It identify the job stressors as role ambiguity, underutilization of skills and work overload. Based on the findings, it revealed that when assessing the level of stress in the workplace on employee performance, majority of the responses indicate neutrality of the responses by responding with "Neither Agree nor Agree" remarks. However; numerous responses also reflects the likelihood of agreement with the impact of stress on employee performance. Applying the correlations and regression reflects a more convincing results. Results from correlation indicates that there is strong correlation of job stress on employee performance $(\mathrm{r}=.955 ; \mathrm{p}=0.000)$. This resulted is supported by various studies of the past $[18,25,31,34,41]$. Findings from regression implies that there significant relationship between underutilization of skills $(\mathrm{p}=.000<0.5)$ and work overload $(\mathrm{p}=.033<0.05)$ and employee performance while role ambiguity has no significant relationship with $\mathrm{p}=0.324$. This result however; contradicts the result from studies of [23, 28].

\section{Recommendations and Further Studies}

From the conclusion, recommendations can be drawn. The company should put consideration on developing the skills of the employees and tapping their potentials. The Human Resource Department may conduct as appropriate skills inventory to identify talents and potentials of employees with proper motivation because this is proven in the study as cause of job stress. Moreover, promotions system may also be given due consideration to encourage the employees to utilize their skills because there are cases where employees are aware of their skills but do not utilize it because they think that there are no returns and benefits of using it. Emphasis should be dealt on minimizing work overloads for employees because this also affects employee performance. Cases of too much works can affect negatively on the employees' performance because this will not only cause stress but would likely result to poor performance.

However; this study recognizes the fact that there are limitations as to the number of respondents, scope of the study and the variables used. Therefore, it is suggested that further studies shall be conducted with larger sample, wider scope and inclusion of more variables as appropriate.

\section{References}

[1] Affum-Osei E., Asante E. A, Forkuoh K. S. (2014). Perceived Stress and Academic Performance of Senior High School Students in Western Region of Ghana. European Journal of Business and Social Sciences, Vol. 2, No. 11 pp. 88-101.

[2] Aghdasi S., Kiamanesh R. A., Ebrahim N. A. (2011). Emotinal Intelligence and Organisational Commitment: Testing the mediatory Role Occupational Stress and Job Satisfaction. Social and Behavioural Sciences, 29, 1965-1976

[3] Ahmed \& Ramzan (2013) Effects of Job Stress on Employees Job Performance: A Study on Banking Sector of Pakistan, IOSR Journal of Business and Management, Vol. 11, Issue 6 pp 61-68.

[4] Ali Y. T., Hassan A., Ali Y. T. \& Bashir R., (2013). Stress Management in Private Banks in Pakistan. Journal of Emerging in Economics and Management Sciences (JETEMS), 4 (3): 308-320.

[5] Ali, Y., et al (2014). Impact of Stress on Job Performance: An Empirical study of the Employees of Private Sector Universities of Karachi, Pakistan. Research Journal of Management Sciences. Vol. 3 (7) pp. 14-17.

[6] Anderson, R. (2003). Stress at work: the current perspective. The journal of the Royal Society for the Promotion of Health, $123(1):$ p. 81

[7] Bashir, S., Ramay, R. I. (2010). Impact of Stress on Employees Job Performance A Study on Banking Sector of Pakistan. International Journal of Marketing Studies, 2 (1).

[8] Chiang, C. X. (1995). A Study of Stress Reactions among Adolescents. Chinese J.

[9] Coetzee S. \& Rothmann (2005). Occupational stress organizational commitment and Ill-Health of employees at a higher Education institution in South Africa. Journal of Industrial Psychology, 31 (1), 47-5 
[10] Daft, R. L. (2005). The leadership experience. (3 ${ }^{\text {rd }}$ Edition). Toronto: Thompson South Western.

[11] Dollard F. M., Winefield R. H. Winefield H. A, Jonge de J. (2000). Psychosocial job strain and productivity in human services workers: A test of the demand-control-support model. Journal of Occupational and Organisational Psychology 73, 501-510. Journal of School Health, 26, 33-37.

[12] Dunmade O. E., Adegoke F. J, Agboola A. A, (2014). Assessment of Ergonomic Hazards and Technostress among the workers of ObafemiAwolowo University ILE-IFE, Osun State, Nigeria. Australian Journal of Business and Management Research, Vol. 4, No. 1, pp. 27-34

[13] Foster, L. B. (2002). Workplace stress: Changing the pattern. Sales and Marketing Journal, p. 32-33.

[14] Gartia R., \&Kumari R., (2012). Relationship between stress and academic Achievement of Senior Secondary School Students: Asian Journal of Multidimensional Research,Vol. 1 (3) pp. 152-160.

[15] Harrold, R., \& Wayland, M. (2002, June). New methods to reduce workplace stress. Industrial Concepts, 19-21.

[16] Imrab, S., Mushtaq, A., Qudsia, B. (2013). Factors Affecting the Motivation of Academic Staff (A case study of University College Kotli,UAJ\&K). International Journal of Business and Management Invention. Vol. 2 No. 1.

[17] Jalagat, R, (2016). Job Performance, Job Satisfaction and Motivation: A Critical Review of their Relationship. International Journal of Advances in Management and Economics (IJAME), 5 (6): 36-43.

[18] Jamal M. (1984). Job Stress and job Performance controversy: an empirical assessment in two countries. Organizational Behavior and Human Performance, 33 (1):121.

[19] Jamal M. (2011). Job stress, Job performance, and Organizational Commitment in a multinational company. An Empirical study in two countries. International Journal of Business and Social Sciences, Vol. 2, No. 2, pp 20-29.

[20] Jeyaraj S. S (2013). Occupational Stress among the Teachers of the Higher Secondary Schools in Mandurai District, Tamil Nadu. IOSR Journal of Business and Management, pp. 63-76.

[21] Kazmi, R., et. al. (2008). Occupational Stress and Its Effects on Job Performance: A Case Study of Medical House Officers of District Abbottabad.

[22] Kebelo K. K. (2012). Occupational Role Stressors as Predictors of Psychological strain among Academic Officers of Higher Educational Institutions. Pakistan Journal of Psychological Research, Vol. 27, No. 2, 173-186.

[23] Lankau, M., Carlson, D. S. and Nielson, T. R. (2006), The mediating influence of role stressors in the relationship between mentoring and job attitudes. Journal of Vocational Behavior, 68 (1): p. 308-322.

[24] Margolis, B. L., Kroes, W. H., \& Quinn, R. P. (1974). Job Stress: An Unlisted Occupational Hazard. Journal of Occupational Medicine, 1 (1): p. 659-661.

[25] Mead R. (2000). What is Stress? Roger Mead Associates, Stress Management, Coaching and Training for Individuals and Groups. Retrieved on December 5, 2016 from, http://www.jpps.com.pk/article/.
[26] Menezes, M. (2005). The Impact of Stress on productivity at Education Training \& Development Practices: Sector Education and Training Authority.

[27] Meyer KE, \& Peng MW. (2006) Probing Theoretically into Central and Eastern Europe: Transaction, Resources, and Institutions. Journal of International Business Studies, 36 (6): 600-621.

[28] Michie, S., and Williams, S. (2003). Reducing psychological ill health and associated sickness absence: A systematic literature review. Occupational and Environmental Medicine, 60 (1): p. 3-9.

[29] Mimura, C and Griffiths, 2003. The effectiveness of current approaches to workplace stress management in the nursing profession: an evidence based literature review. Occupational and Environmental Medicine, Volume 60 (1): p.10-15.

[30] Naqvi H. M. S., Khan A. M., Kant Q. A. Khan N. S (2013). Job Stress and Employeese Productivity, Case of Azad Kashmir, Public Health Sector. Interdisciplinary Journal of Contemporary Research in Business, Vol. 5, No.3, PP 526-542.

[31] Ornelas, S. and Kleiner, B. H. (2003), New Development in Managing Job Related Stress, Journal of Equal Opportunities International 2 (5): p. 64-70.

[32] Parikh, P., Taukari, A., \& Bhattacharya, T. (2004). Occupational stress and coping among nurses. Journal of Health Management, 6 (2): p.115-127.

[33] Rafidah K, Azizah A., Norzaidi D. M., Chong C. S, Salwani I. M. \& Noraini I (2009). The impact of perceived stress and stress factors on academic performance of Pre-Diploma Science Students: A Malaysia Study. International Journal of Research in Education, Vol. 2 (1), 13-26.

[34] Rose M. (2003). Good Deal, Bad Deal? Job Satisfaction in Occupations. Work Employment Society, 17 (1): p.503.

[35] Rumsey, D. (2010). Statistics Essentials for Dummies. $2^{\text {nd }}$ Edition. New York: John Wiley and Sons, Inc.

[36] Sarmiento, R., \& Beale, J. (2007). Determinants of performance amongst shop-floor employees. Management Research News, 30 (12): p.915-927.

[37] Saunders, M., et. al., 2009. Research Methods for Business Students. $5^{\text {th }}$ Edition. England: Pearson Education Limited.

[38] Schultz, D. \& Schultz, E. S. (2002). Psychology and Work Today. (8th edition.). India: Pearson Education, Inc.

[39] Sheena, J., et. al. (2005). The experience of work-related stress across occupations. Journal of Managerial Psychology, 20 (2): p.178-187.

[40] Siu O. (2003). Job Stress and job performance among employees in Hong Kong: the role of Chinese work values and organizational commitment. International Journal of Psychology, 38 (6), 337-347.

[41] Stamper L. C., \& Johlke, C. M. (2003). The Impact of Perceived Organizational Support on the Relationship between Boundary Spanner Role Stress and Work Outcomes. Journal of Management, 29(1): p.569.

[42] Suandi T., Ismail A. I., \& Othman Z. (2014). Relationship between Organisational Climate, Job Stress and Job Performance Officer at State Education Department. International Journal of Education and Literature Studies, Vol. 2, No. 1, pp. 19-28. 
[43] Tiwari, A., \& Balani S., (2013). The Effect of Intervention Program to Reduction of Stress. IOSR Journal of Humanities and Social Science, Vol 9, 27-30.

[44] Treven, S. (2005). Strategies and Programs for Managing Stress in Work Settings. Management, 10 (2): p.45-49.

[45] Velnampy T. \& Aravintham S. A., (2013). Occupational Stress and Organisational Commitment in Private Banks: A Sri Lankan Experience. European Journal of Business Management, Vol. 5 (7) pp. 254-267.

[46] Yahaya L. A., Opekun S. O., \& Idowu A. I. (1996). Stress and
Coping Strategies among Employees in Selected Banks in Nigeria. The Counsellor, Vol. 14, No. 1. pp 14-21.

[47] Yozgat U., Yurtkoru S., Bilginoglu E. (2013). Job stress and job performance among employees in public sector in Istanbul: examining the moderating role of emotional intelligence. Social and Behavioural Sciences, 75, 518-524.

[48] Yunus M. J. \& Mahajar J. A. (2011). Stress and Psychological Well-being of Government Officers in Malasia. Journal of Human Resources and Adult Learning Vol. 7, No. 2, pp. 4050. 